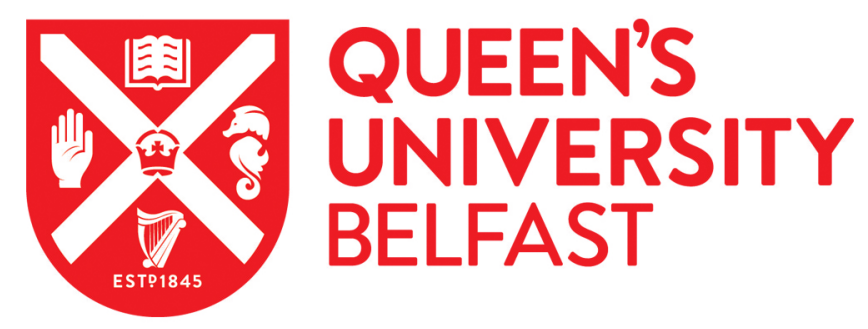

\title{
Does violence beget violence? The role of family ethnic socialization and intergroup bias among youth in a setting of protracted intergroup conflict
}

Taylor, L., \& McKeown, S. (2019). Does violence beget violence? The role of family ethnic socialization and intergroup bias among youth in a setting of protracted intergroup conflict. INTERNATIONAL JOURNAL OF BEHAVIORAL DEVELOPMENT. https://doi.org/10.1177/0165025419844036

\section{Published in:}

INTERNATIONAL JOURNAL OF BEHAVIORAL DEVELOPMENT

\section{Document Version:}

Peer reviewed version

Queen's University Belfast - Research Portal:

Link to publication record in Queen's University Belfast Research Portal

\section{Publisher rights}

(C) 2019 The Authors. This work is made available online in accordance with the publisher's policies. Please refer to any applicable terms of use of the publisher.

\section{General rights}

Copyright for the publications made accessible via the Queen's University Belfast Research Portal is retained by the author(s) and / or other copyright owners and it is a condition of accessing these publications that users recognise and abide by the legal requirements associated with these rights.

Take down policy

The Research Portal is Queen's institutional repository that provides access to Queen's research output. Every effort has been made to ensure that content in the Research Portal does not infringe any person's rights, or applicable UK laws. If you discover content in the

Research Portal that you believe breaches copyright or violates any law, please contact openaccess@qub.ac.uk. 
RUNNING HEADER: POLITICAL CONFLICT, YOUTH AND FAMILY

SOCIALIZATION

Does violence beget violence? The role of family ethnic socialization and intergroup bias among youth in a setting of protracted intergroup conflict

Laura K Taylor ${ }^{1}$

Shelley McKeown ${ }^{2}$

${ }^{1}$ University College Dublin, School of Psychology, Belfield, Dublin 4, Ireland; Queen's University, Belfast; School of Psychology, 18-30 Malone Road, Belfast BT9 5BN; +44 0289097 4217; 1.taylor@qub.ac.uk.

${ }^{2}$ University of Bristol

\section{Acknowledgements}

This work was supported by the Richard Benjamin Trust and the British Academy (BA)/Leverhulme [SG 150807]. Thank you to Jeffrey Hanna, Alexandra Kenny, Clarissa Courtney, Lauren Brown, Dean O’Driscoll, Marion Schulz, Karolina Urbanska, Lukas Horstmeier, Sofia Chirtoglou and Yangjunru (Cecilia) Li for their support with data collection. Our deep appreciation to the numerous school administrators, teachers, and pupils for participating in this project. Any underlying research materials related to this paper can be accessed by contacting the first author. 


\begin{abstract}
Does violence beget violence among youth in a setting of protracted conflict? Framed by a developmental intergroup approach, this paper examines the mediating roles of family ethnic socialization and intergroup bias. Two time points from $466(50 \%$ female $/ 50 \%$ male, $51 \%$ Catholic/49\% Protestant) 14 to 16 year olds in Northern Ireland were analyzed. Bootstrapped chain mediation found that previous experience with sectarianism, or intergroup violence, was positively related to family ethnic socialization, which predicted later intergroup bias, which was related to higher levels of adolescent participation in sectarian antisocial behavior. Findings identify the importance of family processes in the link from experiencing to committing sectarian acts. Implications for preventing youth participation in sectarianism are discussed.
\end{abstract}

Keywords: adolescent, youth, intergroup violence, sectarianism, protracted conflict, family ethnic socialization, intergroup bias, Northern Ireland 
Does violence beget violence? Family ethnic socialization and intergroup bias among youth in a setting of protracted intergroup conflict

This paper aims to understand how young people in the 'post-accord' generation, born after the formal termination of violent conflict, are affected by and contribute to on-going intergroup hostilities. In Northern Ireland, for example, despite the 1998 peace accord, there were approximately 1,000 sectarian incidents reported to the police annually (PSNI, 2017). Young people are often exposed to sectarian antisocial behavior, as well as the direct and active participants in such acts (McEvoy-Levy, 2006; McAuley, 2004). Although rates of exposure may vary across the population, the persistence of perceived threat affects mental health and other outcomes (Shirlow, Taylor, Merrilees, Goeke-Morey, \& Cummings, 2013). In Northern Ireland, understanding if violence begets violence necessitates identifying the processes that may link exposure to sectarian antisocial behavior with participation in sectarianism among youth.

The basic link between exposure to violence and committing such acts may be explained by a number of psychological theories. For example, the Social-Cognitive-Ecological Framework (SCEF; Dubow, Huesmann, \& Boxer, 2009) describes how an individual interacts with the social environment through a process of ecological transactions. Through social learning, events in the social ecology (i.e., family, community, wider society) are observed and the consequences are later recalled. In the SCEF, exposure to violence relates to cognitive biases, such as perceiving ambiguous situations as more threatening, greater attention to threatening symbols and signals, and dampened attention to contradicting cues. These socio-cognitive biases and interactions are reinforced through group identity processes. Moreover, according to SCEF, given intergroup threat and overt hostility, violence will be perceived as a legitimate behavioral 
response in such contexts. Consistent with SCEF, the developmental intergroup framework (DIF; Abrams \& Killen, 2014) emphasizes how youth are actively engaged in observing the social world, making sense of it, and relating those observations to their own behaviors. Thus, in line with these approaches, the current paper recognizes the agency of young people, rather than viewing them as passive recipients of the messages and norms of their social groups.

As part of the ecological transaction with the wider social structures, youth may engage in developmental provocation in their homes. Adapting McDevitt's (2005) model in which youth prompt political conversations with their parents in response to media coverage of an election (see also Kira et al., 2008), the current study examines how exposure to sectarianism may prompt discussions about ingroup identity in Northern Ireland. We hypothesize that when youth are exposed to more intergroup threat they talk to their parents about those experiences. That is, we propose that youth seek information from parents and family members to try to understand conflict-related and intergroup issues. These conversations, in turn, may foster group-based identities, which will guide future behaviors.

These conversations between youth and their families can be understood through the lens of parental or family ethnic socialization (Hughes et al., 2006b). In a comprehensive review, Hughes and colleagues (2006b) outline how both majority and minority parents explicitly and implicitly communicate about cultural heritage and group social status to their children. One of the critical forms of such transmission and discussion is through cultural socialization, or deliberate or implicit ways that parents teach children about their group's history, promote cultural customs and traditions, and foster ingroup pride (Hughes, Bachman, Ruble \& Fuligni, 2006a; Hughes \& Chen, 1999; Umaña-Taylor \& Fine, 2004). This type of socialization is bidirectional with both children and parents playing an active role (Kuczynski, 2003). 
The vast majority of the family ethnic socialization literature, however, has been conducted with ethnic and racial minority families, particularly in the US (see Hughes et al., 2006b, Priest et al., 2014). These studies have found largely positive effects for the role of cultural socialization on youth outcomes, such as such as ethnic knowledge and positive ingroup attitudes (Hughes et al., 2008). Longitudinal research has also found that family ethnic socialization in late adolescence predicted greater ethnic identity exploration and resolution in emerging adulthood (Umaña-Taylor, Zeiders, \& Updegraff, 2013).

The effects of family ethnic socialization, however, are not solely positive for youth development. Another body of research has found that ethnic socialization within the home may be related to ethnic prejudice, intergroup bias, and negative outgroup attitudes (Degner \& Dalege, 2013; Štambuk et al., in press), particularly in settings of entrenched, and sometimes violent, intergroup conflict (Nasie, Diamond, \& Bar-Tal, 2016; Reidy et al., 2015; Taylor, Štambuk, Čorkalo Biruški, \& O'Driscoll, in press). Moreover, intergroup bias, or the degree to which one's ingroup is preferred above the outgroup, is related to support for aggression against the outgroup (Fiske, 2002). Therefore, the current study investigates the extent to which family ethnic socialization and intergroup bias, mediate the link between exposure to sectarianism and later participation in such acts.

\section{Current Paper}

This paper focuses on the 'post-accord' generation in Northern Ireland, those born after the 1998 Belfast/Good Friday Agreement that formally ended the 30-year period of violence known as the Troubles (Cairns \& Roe, 2003). In particular, we focus on adolescence as a key time of group-based identity exploration and commitment (Umaña-Taylor, Bhanot, \& Shin, 2006) in which young people may be exposed to sectarianism and/or commit such acts (Taylor et 
al., 2016). Moreover, compared to emerging adults, adolescents still live at home and have more daily and direct interactions with their families. Therefore, the role of family ethnic socialization may be particularly important for this age group (Umaña-Taylor et al., 2006).

For the first time, the role of family ethnic socialization, specifically cultural socialization, will be examined for youth who identify as being from either a Catholic or Protestant background. ${ }^{1}$ This study expands past research which has examined how group-based narratives have shifted in the post-accord context (Cairns \& Roe, 2003; McAuley \& Ferguson, 2016), particularly among youth (Halliday \& Ferguson, 2016), and the direct effect of exposure to sectarianism and later youth aggression (Taylor et al., 2016). This study specifically examines longitudinal processes (i.e., mediation) linking risk to adversity. This research is important because youth sectarianism not only has consequences at the individual level, but also may contribute to the protracted nature of the conflict even two decades after the peace accord.

\section{Method}

\section{Participants and Procedures}

This project was designed as a two-wave (Spring and Autumn 2016), quasi-experimental study to capture pre/post survey responses surrounding the July 'marching season'; that is, a contentious period associated with intergroup hostility in Northern Ireland when youth would be more likely to participate in sectarian antisocial behavior (McEvoy-Levy, 2006). The larger study (https://pydqub.files.wordpress.com) included a wider-range of relevant research questions (see Taylor \& McKeown, 2017; McKeown \& Taylor, 2017, 2018; Urbanska, McKeown, \& Taylor, 2018); however, the focus of the current paper is on the processes underlying participation in sectarian antisocial behavior.

\footnotetext{
${ }^{1}$ In Northern Ireland, being from the Catholic or Protestant community is understood as an ethnic or social identity, rather than a religious one (Cairns \& Darby, 1998).
} 
The sample size was determined using Cohen's (1992) power primer; we aimed to collect a total of 428, or 107 participants from each of four types of schools: State controlled/Protestant and Maintained/Catholic, and in both interface (i.e., neighborhood with a homogenous Catholic population bordering a neighborhood with a homogenous Protestant population) and noninterface areas (for more detail on sampling and recruitment, see McKeown \& Taylor, 2017, 2018). This sample size ensures a power of .80 to detect a medium effect size for multiple regression with up to eight predictors.

At Time 1, adolescents were $14-15$ years old $(N=466,50 \%$ male, $50 \%$ female; $51 \%$ Catholic, $49 \%$ Protestant $)$ and were $15-16$ years old at Time $2(N=383,52 \%$ male, $48 \%$ female; 47\% Catholic, 53\% Protestant). Inclusion criteria included adolescents who identified as coming from either a Catholic or Protestant community background. Data were collected in schools by a trained research team with the approval of the Ethics Committee at Queen's University Belfast.

All participants were recruited through schools, with principal consent and parental optout, and provided informed assent prior to completing the online questionnaire (approximately 20-35 minutes). Schools were given $£ 100$ for a class party or supplies and adolescents who completed both time points received a $£ 10$ Amazon gift card. Comparing participants from Time 1 who did/did not return at Time 2 , there were no significant differences in participation in sectarianism or family ethnic socialization; however, compared to those who completed Time 2, adolescents who did not return reported more exposure to sectarianism at Time $1(\mathrm{t}(452)=3.71$, $p<.001:$ Mattrited=.96, $\left.\mathrm{SD}=.97 ; \mathrm{M}_{\text {retained }}=.59, \mathrm{SD}=.79\right)$.

\section{Measures}

Exposure to sectarian antisocial behavior (SAB). Developed to assess the frequency of experiencing sectarian antisocial behavior in Northern Ireland, this scale was initially developed 
using focus groups (Taylor et al., 2011) and a two-wave pilot test (Goeke-Morey et al., 2009). Youth reported how often over the last three months, ranging from $0=$ not in the last 3 months to 4 = every day, they had been exposed to series of events. The 12 items included a range in intensity, such as "name calling by people from the other community" to "stones or other objects thrown over walls." Higher scores indicated greater exposure to sectarian antisocial behavior with excellent internal consistency (Time $1 \alpha=.95$ ).

Family ethnic socialization measure (FESM). One aspect of family ethnic socialization, cultural socialization, was included using an adapted scale (Umaña-Taylor \& Fine, 2004; Appendix 1). Adolescents responded to 7 questions about overt and covert aspects of familial ethnic socialization on a 5-point Likert scale from $1=$ not at all true to $5=$ very much true. Overt aspects of familial ethnic socialization included intentional acts from parents and family to socialize the young person based on their ingroup (i.e., Catholic/Protestant). Covert aspects assessed instances of socialization such as family choice of activities or décor. The scale had good internal consistency (Time $1 \alpha=.90)$.

Intergroup bias (IGB). Intergroup attitudes were assessed with two items adapted from (Cairns, Kenworthy, Campbell, \& Hewstone, 2006). Participants rated how they felt overall toward the Protestant and Catholic community, respectively, using a 'feeling thermometer' $(0=$ unfavorable to $100=$ favorable). Intergroup bias was calculated as a difference score between the participants' ingroup and outgroup ratings; thus, scores could range from -100 to 100. Higher intergroup bias represented a stronger preference for the ingroup over outgroup.

Participation in sectarian antisocial behavior (PSAB). This scale was developed for youth in Northern Ireland (Taylor et al., 2016). At both time points, participants reported the frequency with which they did a number of behaviors over the past three months, ranging from 
"Flown a flag" to "Thrown stones or other objects over walls." The response scale was $0=$ never, 1 = not in the last 3 months, $2=$ once in the past 3 months, $3=$ every week, $4=$ every month, and 5 = every day. Higher scores reflected more participation in sectarianism with good internal consistency (Time $1 \alpha=.91$; Time $2 \alpha=.88$ ).

\section{Results}

Table 1 reports the means, standard deviations and bivariate correlations for variables in the current study. Although participation in sectarian antisocial behavior is relatively infrequent, with $36 \%$ reporting never participating and an additional 50\% not in the last 3 months, the critical aspect of this paper is to understand the processes for youth who do report taking part in acts against the outgroup. The most common forms of sectarianism were chanting or flying flags, followed by threatening or calling someone names and wearing a jersey to taunt the other group.

Chain mediation was tested in SPSS using Hayes' Model 6 (Hayes, 2013) with 5,000 bootstrapped replication samples..$^{2}$ The final model (Figure 1) explained $25 \%$ of the variance in adolescent participation in sectarianism at Time 2 and controlling for gender and community background, neither of which was significant, and Time 1 participation levels $(b=.31, \mathrm{se}=.04$, $p<.001)$. Regarding the mediation paths, exposure to sectarian antisocial behavior in the three months prior to Time 1 was significantly related to greater family ethnic socialization at Time 1 $(\mathrm{b}=.30, \mathrm{se}=.10, p<.01)$, which predicted greater intergroup bias at Time $2(\mathrm{~b}=6.05, \mathrm{se}=.88$, $p<.001)$. Intergroup bias was positively related to higher reports of participation in sectarianism at Time $2(\mathrm{~b}=.003, \mathrm{se}=.001, p<.01)$. The specific indirect effect of exposure to sectarianism to later participation was significant $(b=.005, \mathrm{se}=.004 ; 95 \% \mathrm{CI}: .001, .015)$, while the direct effect

2 The substantive results were the same with 1,000 replications; however, following Hayes, Preacher \& Miles (2010), we used the larger replication sample to avoid the potential loss of power (Davidson \& MacKinnon, 2001). 
of Time 1 exposure to sectarianism was no longer a significant predictor of later participation in such acts $(b=.009, \mathrm{se}=.03, n s)$, suggesting full mediation.

\section{Discussion}

The current study found that family ethnic socialization related to later intergroup bias, mediated the link between exposure to sectarianism and participation in such acts. These findings highlight the importance of family processes for adolescent's intergroup attitudes and behaviors in response to risk exposure in the community, particularly among a post-accord generation in a setting of protracted conflict. Interventions aiming to reduce youth participation in intergroup violence, therefore, may need to consider a family-component to help redirect messages around ethnic socialization.

First, adolescents who experienced sectarianism also reported greater ethnic socialization within the family. This finding supports developmental provocation in which young people seek information from those around them to help contextualize the adversity they experience in the community (McAuley, 2004; McDevitt, 2005; Taylor et al., 2017). That is, adolescents who experience outgroup harm turn to their families, who serve as a filter to help young people interpret conflict-related events and understand intergroup relations (Barber, 2013). Viewed through a DIF (Abrams \& Killen, 2014), these results highlight the importance of family processes in settings of intergroup conflict.

Second, perhaps due to the protracted nature of violent intergroup conflict, family ethnic socialization around the ingroup's culture, in this context, was related to greater bias over time. Intergroup bias, in this case, could be related to a greater valuing of the ingroup as a result of cultural socialization. However, "ingroup favoritism, even in the absence of overt antagonism toward outgroups, is not benign" (Brewer, 1999, p. 438). That is, although pride and strength of 
attachment to the ingroup might hold some benefits for young people (Merrilees et al., 2014), it also has been shown to relate to greater outgroup aggression (Merrilees et al., 2013).

Third, consistent with previous research, the current study found a link between intergroup bias and adolescents reporting they committed antisocial behavior against outgroup members. Supporting SCEF (Dubow et al., 2009), adolescents' behavioral choices, such as acting out against the other community, may be shaped by their attitudes, cognitive biases, and group identity processes. For example, in Northern Ireland as in other post-accord settings, even neutral cues may be interpreted as threatening and violent responses may be legitimated (Reidy et al., 2015). These findings converge with qualitative research as to why young people engage in sectarian behavior in a post-accord environment (Halliday \& Ferguson, 2016). Moreover, even if only a relatively small number of youth (15\% in this sample) report such acts in the last 3 months, previous research has shown that perceived sectarian threat has negative consequences for the mental health of the wider community (Shirlow et al., 2013).

Thus, this study extends prior research by demonstrating how exposure to sectarianism may relate to participating in such acts overtime for a post-accord generation of adolescents. Complementing the research on family ethnic socialization (Priest et al., 2014), this is the first to apply this construct in Northern Ireland. The findings suggest that cultural socialization, promoting ingroup pride and knowledge, may have unintended negative consequences in a setting of protracted intergroup conflict. That is, through intergroup bias, family ethnic socialization mediated the link between experiencing sectarian antisocial behavior and perpetuating intergroup conflict.

Although the study investigated these processes over time, in correlational designs, at least three waves of data are recommended for testing mediation (Maxwell \& Cole, 2007). These 
findings should be interpreted with caution and replicated in future with additional time points. Furthermore, all measures were self-report and the study only included one dimension (i.e., cultural) of family ethnic socialization. Although self-report is appropriate for certain constructs, such as the youth's exposure to and participation in sectarianism, future research could use experimental methods to assess intergroup bias, for example, or more fully assess family ethnic socialization by including both parental and child reports. Finally, in adolescence, peers and other social environments, such as schools, take on increased importance (McKeown \& Taylor, 2018); therefore, future research should compare the influence of the family to these other socializing agents (Priest et al., 2014; Reidy et al., 2015).

Interventions aiming to reduce youth participation in intergroup violence, therefore, may need to consider a family-component to help redirect messages around ethnic socialization. Such translational efforts are necessary as participation in sectarian acts not only have individual implications for young people, but also have wider societal implications by perpetuating the conflict in Northern Ireland. Adapting and applying this research approach to understanding the role of family ethnic socialization in other contexts of political violence will also help to shed light on how conflicts persist across generations. 


\section{References}

Abrams, D., \& Killen, M. (2014). Social Exclusion of Children: Developmental Origins of Prejudice. Journal of Social Issues, 70(1), 1-11. doi:10.1111/josi.12043

Barber, B. (2013). Annual Research Review: The experience of youth with political conflict challenging notions of resilience and encouraging research refinement. Journal of Child Psychology and Psychiatry, 54(4), 461-473. doi:10.1111/jcpp.12056

Brewer, M. B. (1999). The psychology of prejudice: Ingroup love and outgroup hate?. Journal of Social Issues, 55(3), 429-444. doi.org/10.1111/0022-4537.00126

Cairns, E., \& Darby, J. (1998). The conflict in Northern Ireland: Causes, consequences, and controls. American Psychologist, 53(7), 754-760. doi.org/10.1037/0003-066X.53.7.754

Cairns, E. \& Roe, M. (2003). The role of memory in ethnic conflict. Hampshire, UK: Palgrave Macmillan.

Cairns, E., Kenworthy, J., Campbell, A., \& Hewstone, M. (2006). The role of in-group identification, religious group membership, and intergroup conflict in moderating ingroup and out-group affect. British Journal of Social Psychology, 45, 701-716. PubMed http://dx.doi.org/10.1348/014466605X69850

Cohen, J. (1992). A power primer. Psychological bulletin, 112(1), 155.

Davidson, R. \& MacKinnon, J. G. (2001). Bootstrap Tests: How Many Bootstraps? Working Papers 1036, Queen's University, Department of Economics. Retrieved from http://qed.econ.queensu.ca/working_papers/papers/qed_wp_1036.pdf

Degner, J., \& Dalege, J. (2013). The apple does not fall far from the tree, or does it? A metaanalysis of parent-child similarity in intergroup attitudes. Psychological Bulletin, 139(6), 1270-1304. doi:10.1037/a0031436 
Dubow, E. F., Huesmann, L. R., \& Boxer, P. (2009). A social-cognitive-ecological framework for understanding the impact of exposure to persistent ethnic-political violence on children's psychosocial adjustment. Clinical Child and Family Psychology Review, 12(2), 113-126. doi: 10.1007/s10567-009-0050-7

Fiske, S. T. (2002). What We Know Now About Bias and Intergroup Conflict, the Problem of the Century. Current Directions in Psychological Science, 11(4), 123-128. doi:10.1111/1467-8721.00183

Goeke-Morey, M. C., Cummings, E. M., Ellis, K., Merrilees, C. E., Schermerhorn, A. C., Shirlow, P., \& Cairns, E. (2009). The differential impact on children of inter- and intracommunity violence in Northern Ireland. Peace and Conflict, 15, 367-383. doi: $10.1080=10781910903088932$

Halliday, D. \& Ferguson, N. (2016). When peace is not enough: The flag protests, the politics of identity \& belonging in East Belfast. Irish Political Studies, 31(4), 525-540.doi $10.1080 / 07907184.2015 .1084291$

Hayes, A.F. (2013). Introduction to mediation, moderation and conditional process analysis: A regression-based approach. New York, NY: The Guilford Press.

Hayes, A. F., Preacher, K. J., \& Myers, T. A. (2010). Mediation and the Estimation of Indirect Effects in Political Communication Research. In E. Bucy \& L. Holbert (Eds.), Sourcebook for political communication research: Methods, measures, and analytical techniques (pp. 434-465). New York: Routledge.

Hughes, D., Bachman, M., Ruble, D., \& Fuligni, A. (2006a). Tuned in or tuned out: Parents' and children's interpretation of parental racial/ethnic socialization practices. In L. Balter \& 
C.S. Tamis-LeMonda (Eds.), Child psychology: A handbook of contemporary issues (pp. 591-610). New York: University Press.

Hughes, D., Rodriguez, J., Smith, E. P., Johnson, D. J., Stevenson, H. C., \& Spicer, P. (2006b). Parents ethnic-racial socialization practices: A review of research and directions for future study. Developmental Psychology, 42(5), 747-770. doi:10.1037/00121649.42 .5 .747

Hughes, D., Rivas-Drake, D., Foust, M., Hagelskamp, C., Gersick, S., \& Way, N. (2008). How to catch a moonbeam: A mixed-methods approach to understanding ethnic socialization in ethnically diverse families. In S. Quintana \& C. McKnown (Eds.) Handbook of race, racism, and child development (pp. 226-277). New Jersey: John Wiley and Sons.

Hughes, D., \& Chen, L. (1999). The nature of parents' race-related communications to children: A developmental perspective. In L. Balter \& C. S. Tamis-Lemonda (Eds.), Child psychology: A handbook of contemporary issues (pp. 467-490). Philadelphia: Psychology Press.

Kira, I. A., Templin, T., Lewandowski, L., Ramaswamy, V., Ozkan, B., \& Mohanesh, J. (2008). The physical and mental health effects of Iraq War media exposure on Iraqi refugees. Journal of Muslim Mental Health, 3(2), 193-215. doi.org/10.1080/15564900802487592 Kuczynski, L. (2003). Beyond bidirectionality: Bilateral conceptual frameworks for understanding dynamics in parent-child relations. In Kuczynski, L. (Ed.), Handbook of Dynamics in Parent-Child Relations (pp. 3-24). Sage Publications, Inc.

Maxwell, S. E., \& Cole, D. A. (2007). Bias in cross-sectional analyses of longitudinal mediation. Psychological Methods, 12(1), 23-44. doi:10.1037/1082-989X.12.1.23 
McAuley, J. W. (2004). Peace and progress? Political and social change among young loyalists in Northern Ireland. Journal of Social Issues, 60(3), 541-562. doi.org/10.1111/j.00224537.2004.00371.x

McAuley, J. W. \& Ferguson, N. (2016). "Us" and "them": Ulster Loyalist perspectives on the IRA and Irish Republicanism. Terrorism and Political Violence, 28(3), 561-575. doi $10.1080 / 09546553.2016 .1155938$

McDevitt, M. (2005). The Partisan Child: Developmental Provocation as a Model of Political Socialization. International Journal of Public Opinion Research, 18(1), 67-88. doi:10.1093/ijpor/edh079

McEvoy-Levy, S. (2006). Politics, protest, and local "power sharing" in North Belfast. In S. McEvoy-Levy (Ed.), Troublemakers or peacemakers? Youth and post-accord peace building (pp. 139-172). Notre Dame: University of Notre Dame Press.

McKeown, S. \& Taylor, L. K. (2018). Perceived peer and school norm effects on youth antisocial and prosocial behaviours through intergroup contact in Northern Ireland. British Journal of Social Psychology, 57(3), 652-665. doi.org/10.1111/bjso.12257

McKeown, S. \& Taylor, L. K. (2017). Intergroup contact and peacebuilding: Promoting youth civic engagement in Northern Ireland. Journal of Social and Political Psychology, 5(2), 415-434.

Merrilees, C. E., Taylor, L. K., Goeke-Morey, M. C., Shirlow, P., Cummings, E., \& Cairns, E. (2014). The protective role of group identity: Sectarian antisocial behavior and adolescent emotion problems. Child Development, 85(2), 412-420. doi:10.1111/cdev.12125 
Merrilees, E. M., Cairns E., Taylor, L. K., Shirlow, P., Goeke-Morey, M., \& Cummings, E. M. (2013). Social identity and youth aggressive and delinquent behaviors in a context of political violence. Political Psychology, 34(5), 695-711. doi:10.1111/pops.12030

Nasie, M., Diamond, A. H., \& Bar-Tal, D. (2016). Young Children in Intractable Conflicts. Personality and Social Psychology Review, 20(4), 365-392. doi:10.1177/1088868315607800

Police Service of Northern Ireland (PSNI) (2017). Incidents and Crimes with a Hate Motivation Recorded by the Police in Northern Ireland: Quarterly Update to 31 March 2017. Retrieved from https://www.psni.police.uk/globalassets/inside-the-psni/ourstatistics/hate-motivation-statistics/2016-17/q4/quarterly-hate-motivations-bulletinperiod-ending-mar17.pdf

Priest, N., Walton, J., White, F., Kowal, E., Baker, A., \& Paradies, Y. (2014). Understanding the complexities of ethnic-racial socialization processes for both minority and majority groups: A 30-year systematic review. International Journal of Intercultural Relations, 43, 139-155. doi:10.1016/j.ijintrel.2014.08.003

Reidy, C. M., Taylor, L. K., Merrilees, C. E., Ajduković, D., Biruški, D. Č, \& Cummings, E. M. (2015). The political socialization of youth in a post-conflict community. International Journal of Intercultural Relations, 45, 11-23. doi:10.1016/j.ijintrel.2014.12.005

Shirlow, P., Taylor, L.K., Merrilees, C. E., Goeke-Morey, M. C., \& Cummings, E. M. (2013). Hate crime: Record or perception? Space \& Polity, 17(2), 237-252.

Štambuk, M., Taylor, L. K., Löw, A., Čorkalo Biruški, D., Merrilees, C. E., Ajduković, D., \& Cummings, E. M. (in press). Parental competitive victimhood and interethnic 
discrimination among their children: The mediating role of ethnic socialization and symbolic threat to the in-group. British Journal of Social Psychology.

Taylor, L. K., \& McKeown, S. (2017). Youths’ peacebuilding potential: Intergroup contact and civic participation amongst a post-accord generation in Northern Ireland. In K. Niven, S. Lewis, \& C. Kagan (Eds.), Making a difference with psychology (pp. 56-62). London, UK: Richard Benjamin Trust.

Taylor, L. K., Merrilees, C. E., Campbell, A., Shirlow, P., Cairns, E., Goeke-Morey, M.C., Schermerhorn, A. C., \& Cummings, E. M. (2011). Sectarian and nonsectarian violence: Mothers' appraisals of political conflict in Northern Ireland. Peace and Conflict: Journal of Peace Psychology, 17(4), 343-366. doi:10.1080/10781919.2011.610199

Taylor, L. K., Merrilees, C. E., Goeke-Morey, M. C., Shirlow, P., \& Cummings, E. M. (2016). Trajectories of Adolescent Aggression and Family Cohesion: The Potential to Perpetuate or Ameliorate Political Conflict. Journal of Clinical Child \& Adolescent Psychology, 45(2), 114-128. doi:10.1080/15374416.2014.945213

Taylor, L. K., Štambuk, M., Čorkalo Biruški, D., \& O’Driscoll, D. (in press). Transgenerational transmission of collective victimhood through a developmental intergroup framework: The lasting power of group narratives of suffering. In J. Vollhardt (Ed.), The Social Psychology of Collective Victimhood. United Kingdom: Oxford University Press.

Taylor, L. K., Townsend, D., Merrilees, C. E., Goeke-Morey, M. C., Shirlow, P., \& Cummings, E. M. (2017). Adolescent civic engagement and perceived political conflict: The role of family cohesion. Youth \& Society. doi.org/10.1177/0044118X17697236 
Umaña-Taylor, A. J., Bhanot, R., \& Shin, N. (2006). Ethnic identity formation during adolescence: The critical role of families. Journal of Family Issues, 27(3), 390-414. doi.org/10.1177/0192513X05282960

Umaña-Taylor, A. J., \& Fine, M. A. (2004). Examining Ethnic Identity among Mexican-Origin Adolescents Living in the United States. Hispanic Journal of Behavioral Sciences, 26(1), 36-59. doi:10.1177/0739986303262143

Umaña-Taylor, A. J., Zeiders, K. H., \& Updegraff, K. A. (2013). Family ethnic socialization and ethnic identity: A family-driven, youth-driven, or reciprocal process? Journal of Family Psychology, 27(1), 137-146. doi:10.1037/a0031105

Urbanska, K., McKeown, S., \& Taylor, L. K. (2018). From injustice to action: The role of empathy and perceived fairness to address inequality via victim compensation. Journal of Experimental Social Psychology. doi:10.17605/OSF.IO/83V4U 
Table 1

Means, standard deviations, and bivariate correlations $(N=466)$

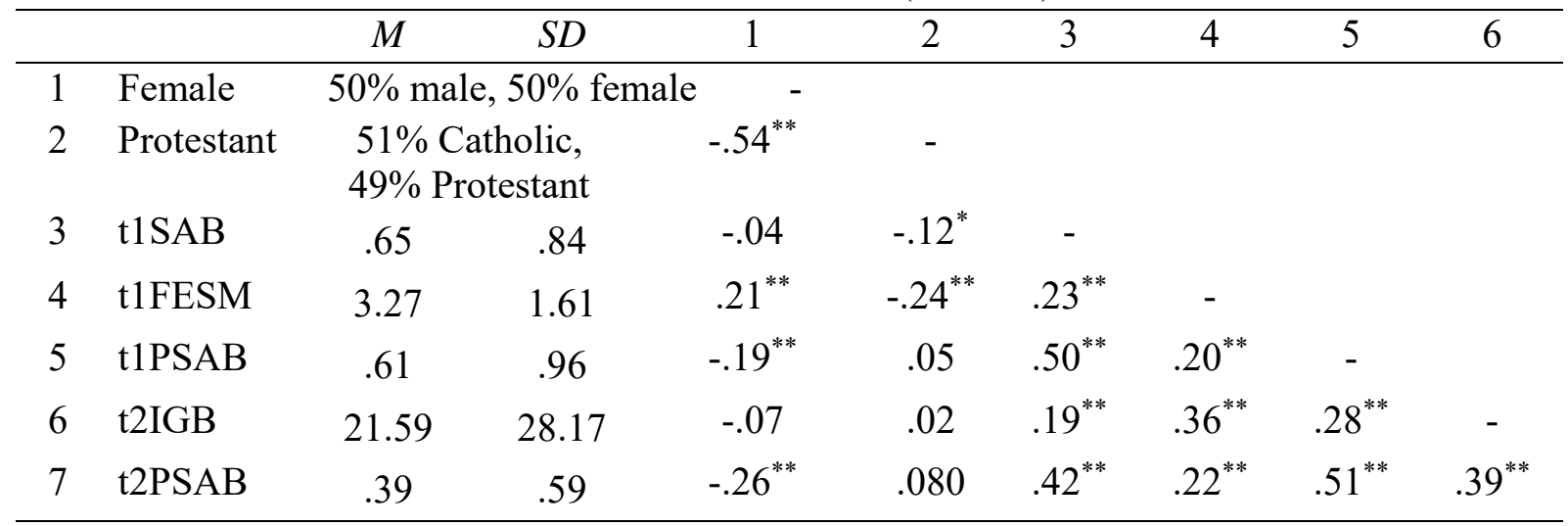

Note: $* p<.05, * * p<.01 ; \mathrm{t} 1=$ Time $1, \mathrm{t} 2=$ Time $2 ; \mathrm{SAB}=$ exposure to sectarian antisocial behavior; FESM = family ethnic socialization measure; IGB = intergroup bias; PSAB = participation in sectarian antisocial behavior. 
Figure 1

Chain Mediation of Adolescent Exposure to Sectarian Antisocial Behavior and Family Ethnic Socialization, at Time 1, on Intergroup Bias and Participation in Sectarian Antisocial Behavior, at Time 2. Controls of Gender, Ethnicity and Participation in Sectarian Antisocial Behavior at Time 1 are Omitted for Readability. Indirect Effect Depicted with a Dotted Line. Unstandardized Regression Coefficients with Standard Errors in Parentheses are Reported. ${ }^{*} p<.05 ;{ }^{*} p<.01$; $* * * p<.001$.

.005 (.004), 95\% CI: .0003, .0152

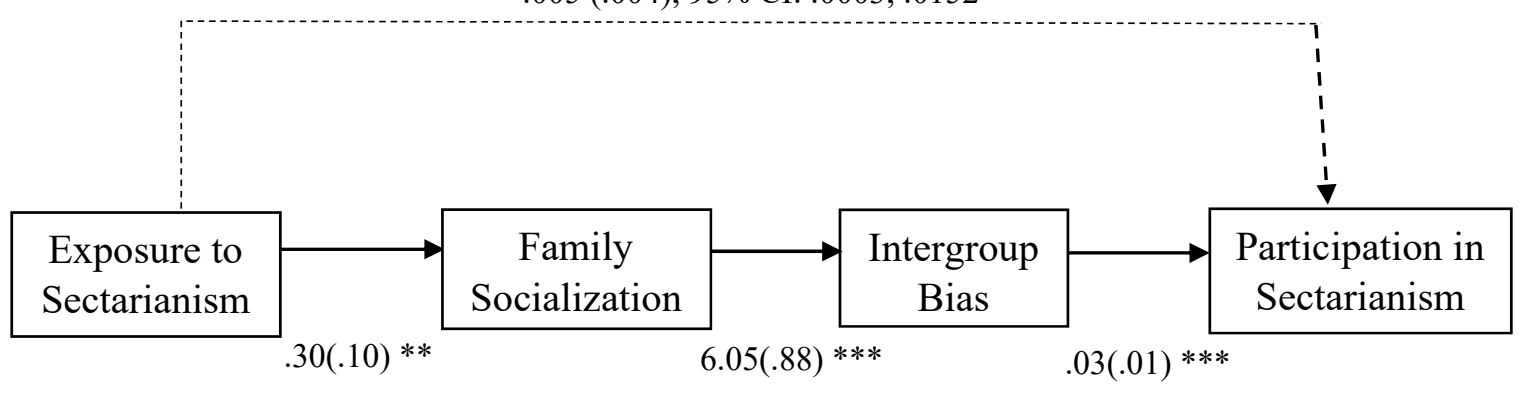




\section{Appendix 1}

Familial Ethnic Socialization Measure

Response scale: $0=$ Not at all to $6=$ Very much so

Instructions: Please rate how much you agree with each of the following items:

1. My family teaches me about the values and beliefs of our $<$ ingroup $>$ background

2. My family teaches me about the history of my $<$ ingroup $>$ background

3. Our home is decorated with things that reflect my $<$ ingroup $>$ background

4. My family celebrates holidays that are specific to my $<$ ingroup $>$ background

5. My family attends things such as activities, concerts, plays, festivals, or other events that represent my <ingroup $>$ background

6. The people who my family hangs out with the most are people who share the same $<$ ingroup $>$ background as my family

7. My family feels a strong attachment to our $<$ ingroup $>$ background 